\title{
THE CONTENT OF CARBON AND HYDROGEN IN GRASS BIOMASS AND ITS INFLUENCE ON HEATING VALUE
}

\author{
Aleksandrs Adamovics ${ }^{1}$, Rasma Platace ${ }^{1}$, Inguna Gulbe ${ }^{2}$, Semjons Ivanovs ${ }^{1}$ \\ ${ }^{1}$ Latvia University of Life Sciences and Technologies, Latvia; \\ ${ }^{2}$ Institute of Agricultural Resources and Economics - "Priekuli", Latvia \\ aleksandrs.adamovics@1lu.lv,rasmins@inbox.lv, inguna.gulbe@arei.lv, semjons@apollo.lv
}

\begin{abstract}
Carbon $(\mathrm{C})$, hydrogen $(\mathrm{H})$, and oxygen $(\mathrm{O})$ are the main chemical elements that determine the heating value of fuels. By combustion of biomass, $\mathrm{C}$ and $\mathrm{H}$ oxidize in an exothermic reaction. The carbon content in biomass is considerably higher $(\sim 45 \%)$ than the hydrogen content $(\sim 6.5 \%)$. In contrast, the heating value of $\mathrm{H}$ is approximately seven times higher than that of $\mathrm{C}$. The more hydrogen per carbon, the lower the oxidation state and the more energy that will be released during the oxidation reaction, which is characterized by $\mathrm{C} / \mathrm{H}$ ratio. In our study, the highest carbon content was detected in the mixtures (1/3) of tall fescue with osier $(46.6 \%)$ and reed canary grass with grey alder $(46.9 \%)$, whereas the lowest values were detected in the mixtures $(3 / 1)$ of tall fescue with hybrid aspen $(43.7 \%)$ and reed canary grass with osier $(43.4 \%)$. The highest hydrogen content was found in timothy $(5.93 \%)$ and birch $(6.83 \%)$. In grass biomass, $\mathrm{H}$ content was on average $6 \%$ lower than in wood biomass.
\end{abstract}

Keywords: grasses, biomass mixtures, carbon, hydrogen.

\section{Introduction}

The main combustible chemical elements of solid fuels (including grass biomass) are carbon (C) and hydrogen $(\mathrm{H})$. Oxygen $(\mathrm{O})$, sulfur $(\mathrm{S})$ and partly nitrogen $(\mathrm{N})$ also participate in the burning process [1]. During combustion, $\mathrm{C}$ and $\mathrm{H}$ are oxidised, and exothermic reactions lead to the formation of $\mathrm{CO}_{2}$ and $\mathrm{H}_{2} \mathrm{O}$ [2]. The calorific value of a fuel depends on the content of $\mathrm{C}, \mathrm{H}, \mathrm{O}$, and $\mathrm{N}$. As the $\mathrm{H}$ and $\mathrm{C}$ contents increase in biomass, the higher heating value (HHV) index increases but the calorific value of $\mathrm{O}$ decreases $[3 ; 4]$. The studies conducted at the Latvia University of Life Sciences and Technologies showed that the highest calorific value of the biomass of reed canary grass harvested in the autumn was $15.14 \mathrm{MJ} \cdot \mathrm{kg}^{-1}$, whereas in spring it was $16.84 \mathrm{MJ} \cdot \mathrm{kg}^{-1}$ [5; 6]. In general, the highest calorific value of the grass and dry wood biomass fluctuated between 17 and $21 \mathrm{MJ} \cdot \mathrm{kg}^{-1}$, but the lowest calorific value fluctuated between 16 and $20 \mathrm{MJ} \cdot \mathrm{kg}^{-1}$. Wood biomass has a slightly higher calorific value than grass biomass, and its calorific value is linearly dependent on and inversely proportional to the moisture content [3].

Carbon is the main burning element of a fuel; it can generate energy in the form of heat, which can then be converted into other forms of energy such as steam, electricity, etc.

Hydrogen is the second major combustible element; its calorific value is greater than that of carbon. Hydrogen content in wood and peat is low [1]. In biomass, $\mathrm{H}$ content ranges between $3 \%$ and $11 \%$ (on average $6.3 \%$ ), which is higher than on average for fossil fuels (5.4\%), taking into consideration that biomass contains four times more oxygen and less carbon, which results in a lower calorific value of biomass.

Elemental ratio. The classification of fuels, which is based on the elemental $(\mathrm{H} / \mathrm{C})$ and $(\mathrm{O} / \mathrm{C})$ ratios, allows better understanding of the factors affecting the calorific value of a fuel. For example, the highest calorific value correlates with the oxygen/carbon $(\mathrm{O} / \mathrm{C})$ ratio, changing the higher calorific values from 15 to $38 \mathrm{MJ} \cdot \mathrm{kg}^{-1}$ and changing also the $\mathrm{O} / \mathrm{C}$ ratio from 0.1 to 0.7 . In contrast, the increase in the $\mathrm{H} / \mathrm{C}$ ratio reduces the calorific value of a fuel [7].

\section{Materials and Methods}

Solid fuel biomass granules consisted of mixtures of dry powder biomass from grasses and wood $(\varnothing<1 \mathrm{~mm})$ in various proportions: a mixture of $1 / 3$ (25\% wood $+75 \%$ grass); a mixture of $1 / 1(50 \%$ wood $+50 \%$ grass); and a mixture of $3 / 1$ (75\% wood $+25 \%$ grass). Single-component $(100 \%)$ granules of grasses and wood pulp were used for control. The wood biomass powder was obtained from the scientific research institute "Silava" in Salaspils, Latvia.

Solid fuel granule mixtures were made from the following components: (1) grasses - reed canary grass (Phalaris arundinaceae (L.) Raush.), festulolium ( $\times$ Festulolium Asch. \& Graebn.), timothy 
(Phleum pratense L.), meadow fescue (Festuca pratensis Huds. ), and tall fescue (Festuca arundinaceae Schreb.); and (2) wood - birch (Betula pendula Roth.), osier (Salix spp.), grey alder (Alnus incana (L.) Moench), aspen (Populus tremula L.), and hybrid aspen (Populus tremuloides $\times$ Populus tremula).

Grass biomass was obtained from the first cut of grasses of the first and second year use. After drying, the samples were crushed with the electric grinder "ЭМ-ЗА УХЛ 4.2" at the Latvia University of Life Sciences and Technologies Agronomic Analysis Research Laboratory. The grass and wood powders were pressed in granules with the manual press "IKA WERKE".

Carbon content was determined by the analyser CS-500; the hydrogen content was determined according to ISO 625, LVS EN 15104. Chemical analyses were carried out at the Latvia University of Life Sciences and Technologies Agronomic Analysis Research Laboratory and at the "Laboratory of Testing and Research of Waste Products and Fuels "Virsma" Ltd.

Data mathematical processing was performed using the program "Microsoft Excel for Windows 2000".

\section{Results and Discussion}

The carbon content in the biomass of grass species studied varied from $42.0 \%$ in meadow fescue to $48.81 \%$ in timothy (Table 1). Scientists S. V. Vassilev, D. Baxter, L. K. Andersen and C. G. Vassileva (2010) found that the carbon content in grasses fluctuated on average between $49 \%$ and $50 \%[8]$.

On average in all trial variants, the $\mathrm{C}$ content in the biomass of first cut grass of the first year of use (2012) varied from $46.39 \%$ (tall fescue) to $48.49 \%$ (timothy), whereas in the biomass of the second year grass use (2013), it varied from $42.18 \%$ (meadow fescue) to $42.76 \%$ (tall fescue). In 2013 , the reduction in the carbon content in the grass biomass ranged between $8 \%$ (tall fescue) and $13 \%$ (for timothy). This difference can be explained by differences in the meteorological conditions of the respective years.

Table 1

Carbon content in grass biomass $(\%)$

\begin{tabular}{|c|c|c|c|c|c|c|}
\hline \multirow[b]{2}{*}{$\begin{array}{c}\text { Grass } \\
\text { species }\end{array}$} & \multirow[b]{2}{*}{ Year } & \multicolumn{5}{|c|}{ Variant of fertilizer application } \\
\hline & & $\begin{array}{c}\text { No } \\
\text { P0K0 } \\
\text { (control) }\end{array}$ & $\begin{array}{c}\text { N0 } \\
\text { P80K120 } \\
\text { (background) }\end{array}$ & $\begin{array}{c}\text { N30 } \\
\text { P80K120 }\end{array}$ & $\begin{array}{c}\text { N90 } \\
\text { P80K120 }\end{array}$ & $\begin{array}{c}\text { N180 } \\
\text { P80K120 }\end{array}$ \\
\hline \multirow{3}{*}{$\begin{array}{l}\text { Reed } \\
\text { canary } \\
\text { grass }\end{array}$} & 2012 & 47.43 & 47.12 & 47.28 & 47.73 & 47.84 \\
\hline & 2013 & 42.90 & 42.04 & 42.84 & 42.95 & 42.76 \\
\hline & average & 44.93 & 44.53 & 45.02 & 45.32 & 45.35 \\
\hline \multirow{3}{*}{$\begin{array}{l}\text { Festulo- } \\
\text { lium }\end{array}$} & 2012 & 46.48 & 46.85 & 47.02 & 47.62 & 47.90 \\
\hline & 2013 & 42.62 & 43.09 & 42.52 & 42.36 & 42.82 \\
\hline & average & 44.47 & 44.78 & 44.57 & 44.91 & 45.28 \\
\hline \multirow{3}{*}{ Timothy } & 2012 & 48.81 & 48.05 & 48.74 & 48.51 & 48.41 \\
\hline & 2013 & 42.44 & 42.63 & 43.00 & 42.24 & 42.15 \\
\hline & average & 45.16 & 44.94 & 45.78 & 45.32 & 45.21 \\
\hline \multirow{3}{*}{$\begin{array}{l}\text { Meadow } \\
\text { fescue }\end{array}$} & 2012 & 47.89 & 48.19 & 48.02 & 47.15 & 48.27 \\
\hline & 2013 & 42.13 & 42.52 & 42.19 & 42.00 & 42.14 \\
\hline & average & 44.65 & 44.73 & 44.77 & 44.25 & 45.05 \\
\hline \multirow{3}{*}{ Tall fescue } & 2012 & 46.40 & 46.21 & 46.12 & 46.07 & 46.91 \\
\hline & 2013 & 42.58 & 42.93 & 42.83 & 42.69 & 42.76 \\
\hline & average & 44.41 & 44.60 & 44.43 & 44.34 & 45.02 \\
\hline \multirow{3}{*}{$\begin{array}{l}\text { Average of } \\
\text { all species }\end{array}$} & 2012 & 47.28 & 47.19 & 47.43 & 47.46 & 47.85 \\
\hline & 2013 & 42.55 & 42.65 & 42.67 & 42.44 & 42.51 \\
\hline & average & 44.71 & 44.71 & 44.92 & 44.84 & 45.18 \\
\hline
\end{tabular}


According to the findings of R. R. Bakker and H. W. Elbersen, differences in the ash content were detected in relation to the water consumption, as with the amount of water absorbed a plant also absorbs more chemical elements, which contributes to the increase in the ash content [9]. Besides, among the chemical elements taken up, there is also carbon that the plant absorbs from the soil.

In the variant without fertilizers, the C content was on average $44.71 \%$ - varying from $44.41 \%$ in tall fescue to $45.16 \%$ in timothy.

Changes in the carbon content resulting from phosphorus and potassium (P80K120) fertilizer use were different for different grass species. In both years of grass use, the $\mathrm{C}$ content in the biomass of the first cut grass was lower in reed canary grass and higher in meadow fescue compared to the control fertilizer variant.

The use of nitrogen fertilizer increased the $\mathrm{C}$ content for all grass species: on average by $0.5 \%$ with a nitrogen norm of $30 \mathrm{~kg} \cdot \mathrm{ha}^{-1} \mathrm{~N}$ and by $1.1 \%$ with a nitrogen norm of $180 \mathrm{~kg} \cdot \mathrm{ha}^{-1} \mathrm{~N}$.

The carbon content in plants is homogeneous, with slight differences between wood and grasses. In our study, the $\mathrm{C}$ content in grasses was $4-8 \%$ less than in wood pulp. In the grass and wood mixtures, the carbon content increased with the increase in the proportion of wood pulp (Fig. 1).

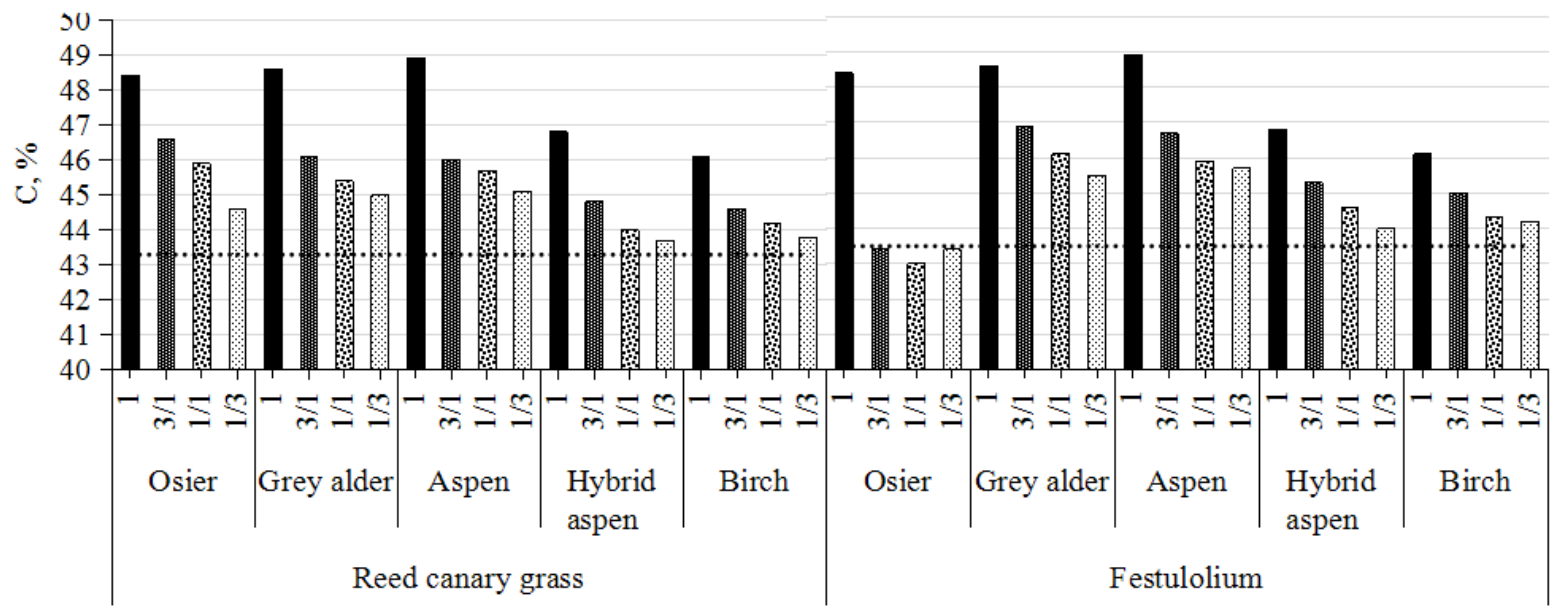

Note: proportions $3 / 1,1 / 1$, and $1 / 3$ - wood biomass / grass biomass.

Fig. 1. Carbon (C) content in biomass of grasses and wood pulp and in their mixtures

The highest carbon content was detected in the mixture of $1 / 3$ for festulolium with osier $(46.6 \%)$ and for reed canary grass with gray alder $(46.9 \%)$, whereas the lowest rates were detected in the mixture of $3 / 1$ for festulolium with hybrid aspen $(43.7 \%)$ and for reed canary grass with osier $(43.4 \%)$.

The hydrogen content in a fuel influences its calorific value: the more hydrogen, the higher the calorific value. The hydrogen content in grass species samples varied from $5.48 \%$ in timothy to $5.93 \%$ in tall fescue (Fig. 2).

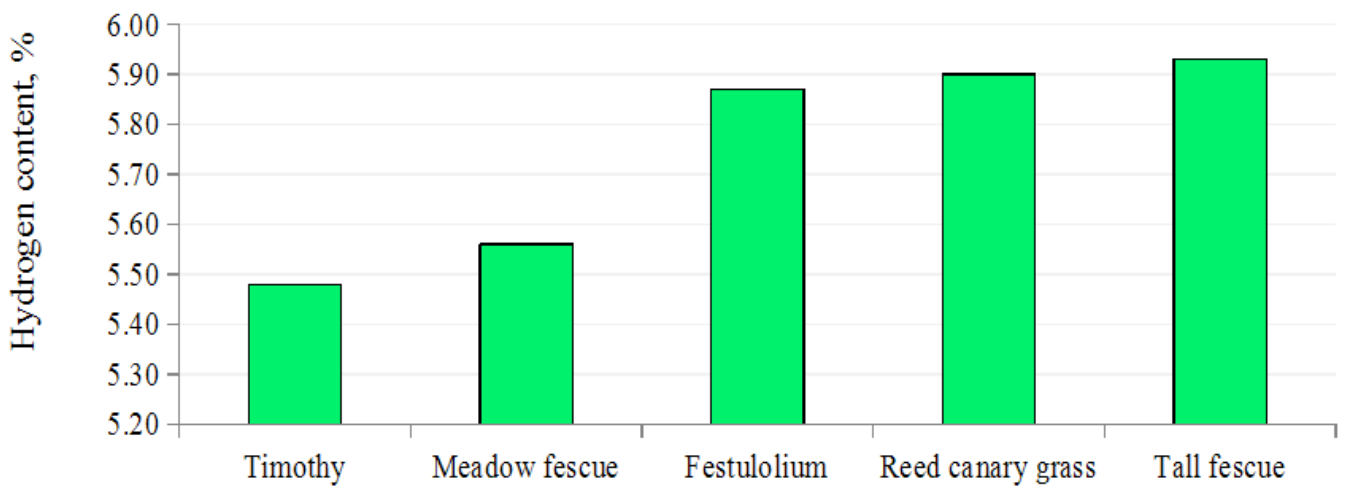

Fig. 2. Hydrogen content in grass biomass by grass specie 
The H/C ratio (1.51-1.52) of some grasses such as festulolium, reed canary grass and tall fescue was similar to that of aspen, hybrid aspen and grey alder - 1.52 (Fig. 3). The highest index was for osier and birch -1.54 . In the mixtures of aspen and grasses, the $\mathrm{H} / \mathrm{C}$ ratio increased with the increase in the amount of wood; however, this increase was not large - from $0.5 \%$ to $2 \%$.

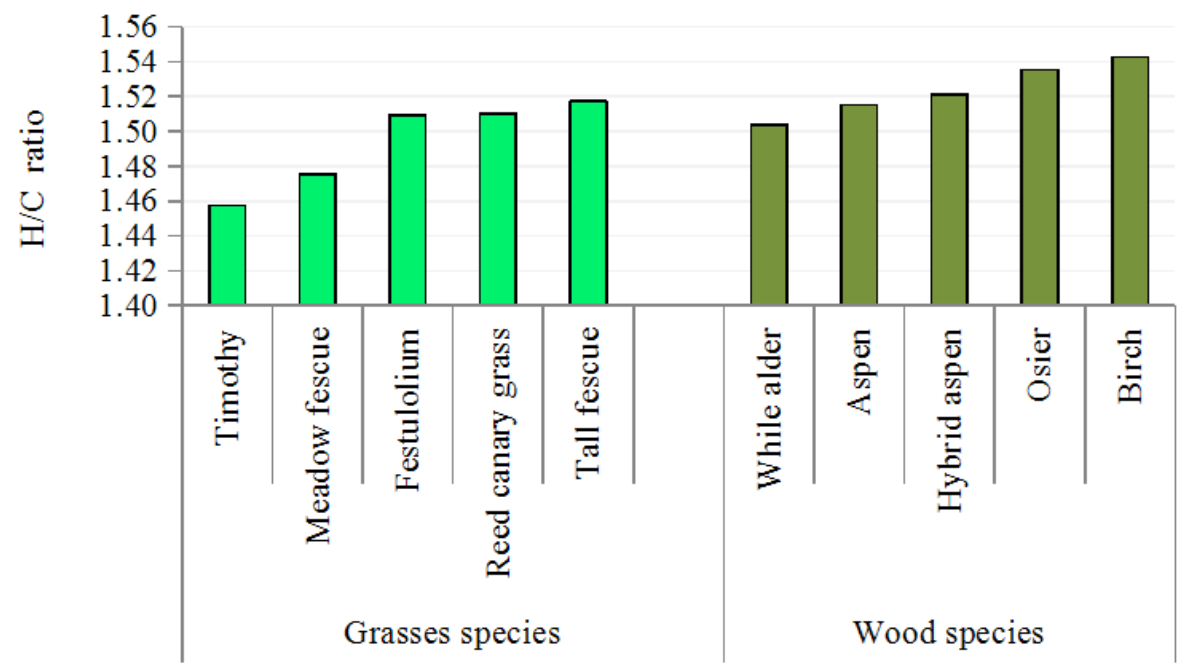

Fig. 3. Ratio of hydrogen and carbon $(\mathrm{H} / \mathrm{C})$ in grass and wood biomass

The hydrogen and carbon contents indicate the energy content of a fuel, which is characterized by the atomic ratio $\mathrm{H} / \mathrm{C}$ of these elements. The more hydrogen per carbon, the lower the oxidation rate and the more energy is released in the oxidation reaction. Consequently, the higher the atomic $\mathrm{H} / \mathrm{C}$ ratio, the more energy that is released from burning a fuel. The average $\mathrm{H} / \mathrm{C}$ ratio for lignocellulosic biomass is 1.5 [10]. In our research, among all grass species studied, the highest $\mathrm{H} / \mathrm{C}$ ratio (1.52) was in tall fescue, but the lowest $\mathrm{H} / \mathrm{C}$ ratio (1.45) was in timothy. Among the wood biomass samples, the highest $\mathrm{H} / \mathrm{C}$ ratio was in birch -1.54 (Fig. 3). Overall, the $\mathrm{H} / \mathrm{C}$ ratios of the biomass samples studied did not differ markedly - the average $\mathrm{H} / \mathrm{C}$ ratio in grasses was $2.3 \%$ lower than in wood.

\section{Conclusions}

1. In the biomass of the first cut grasses of the first and second year use, the content of $\mathrm{C}$ varied from $42.00 \%$ in meadow fescue to $48.81 \%$ in timothy, while the $\mathrm{H}$ content varied from $5.48 \%$ in timothy to $5.93 \%$ in tall fescue.

2. The impact of the phosphorus and potassium (P80K120) fertilizer on the C content in grass biomass differed for different grass species. Compared with the control variant, the $\mathrm{C}$ content was lower in reed canary grass and higher in meadow fescue, whereas in other grass species it was dependent on the growing conditions in the respective year.

3. Nitrogen fertilizers contributed to an increase in the carbon content of grasses on average by 0.5$1.1 \%$. Out of all grass species, only reed canary grass was not affected by the year's growing conditions - its biomass demonstrated a steady increase in the $\mathrm{C}$ content in all fertilizer variants.

4. Among all biomass samples of grass species, the highest $\mathrm{H} / \mathrm{C}$ atomic ratio (1.52) was in tall fescue, but the lowest (1.45) - in timothy.

\section{Acknowledgements}

The research was supported by a grant of the Ministry of Agriculture of the Republic of Latvia.

\section{References}

[1] Cars A. Energoresursi (Energy resources). Rīga: SIA Baltic Communication Partners, 2008. 102 lpp. (In Latvian).

[2] Obernberger I., Brunner T., Barnthaler G. Chemical properties of solid biofuels - significance and impact. Biomass and Bioenergy, No. 30, 2006. pp. 973-982.

[3] Spliethoff H. Power Generation from Solid Fuels. Springer, 2010. 674 p. 
[4] Saidur R., Abdelaziz E.A., Demirbas A. etc. A review on biomass as a fuel for boilers. Renewable and Sustainable Energy Reviews. No. 15, 2011. pp. 2262-2289.

[5] Kakitis A., Ancans D., Nulle I. Evaluation of combustion properties of biomass mixtures. Proceedings of the $13^{\text {th }}$ International Scientific conference "Engineering for Rural Development", May 29 -30, 2014, Jelgava, Latvia, pp. 423-427.

[6] Kakīitis A., Nulle I., Ozollapins M. etc. Assessment of combustion parameters of biomass mixtures. Proceedings of the $14^{\text {th }}$ International Scientific conference "Engineering for Rural Development", May 20 -22, 2015, Jelgava, Latvia, pp. 133-140.

[7] Jones J.M., Nawaz M., Darvell L.I. etc. Towards biomass classification for energy applications. Science in Thermal and Chemical Biomass Conversion. A.V. Bridgwater, D.G.B. Boocock (Eds.).Vol. 1. CPL Press, 2006. pp. 331-339.

[8] Vassilev S.V., Baxter D., Andersen L.K. etc. An overview of the composition and application of biomass ash. Part 2: Potential utilisation, technological and ecological advantages and challenges. Fuel, No. 105, 2013. pp. 19-39.

[9] Bakker R.R., Elbersen H.W. Managing ash content and quality in herbaceous biomass: An analysis from plant to product. 14th European Biomass Conference and Exhibition, October 17, 2005, Paris, France, 2005, pp. 210-213.

[10] Lehmann J., Joseph S. (Eds.) . Biochar for Environmental Management: Science and Technology. Routledge, 2009. 448 p. 